\title{
Educating Burmese migrants working in Thailand with HIV/AIDS public health knowledge - a perspective of public health officers
}

\author{
Smith Boonchutima, Suchitra Sukonthasab, Parichart Sthapitanonda \\ Chulalongkorn University, Bangkok, Thailand
}

\begin{abstract}
Introduction: Migrants' vulnerability to HIV/AIDS remains a major public health issue in Thailand. Good knowledge, practices, and migrants' attitudes towards HIV/AIDS are essential to prevent new HIV infections and spread of the disease. A prudent HIV/AIDS prevention initiative requires sharing of clear and relevant information concerning the cause, spread, symptoms, prevention, treatment, and the right to treatment of HIV/AIDS.

Material and methods: The data was extracted using a questionnaire administered among 106 public health officers drawn from the Bureau of Risk Communication and Health Behaviour Development, Department of Disease Control (DDC) in Thailand. It was analysed using SPSS version 22 with descriptive statistics and multiple correlation analysis performed to infer findings.

Results: A total of 66 women and 40 men participated in this study. No compelling mandate from the government was found demanding public health officers have to interact with Burmese migrants to improve public health knowledge on HIV/AIDS. A significant number of the officers had never interacted with these migrants in conveying HIV/AIDS information. Most of the Burmese migrants experienced major problems receiving information on HIV/AIDS. They preferred the use of group training in the workplace in communicating information about the prevention, causes, spread, and symptoms of HIV/AIDS.

Conclusions: Burmese migrant workers have low levels of information about the symptoms, prevention, causes, spread, and treatment of HIV/AIDS. Public health officers should utilise group training in migrants' workplaces, posters, and flyers in administering intervention programs.
\end{abstract}

HIV AIDS Rev 2017; 16, 4: 226-235

DOI: https://doi.org/10.5114/hivar.2017.72029

Key words: Thailand, migrants, HIV knowledge, Myanmar, public health officers.

\section{Introduction}

Acquired immunodeficiency syndrome and human immunodeficiency virus (HIV/AIDS) has remained one of the greatest threats to human existence for approximately three decades.
Since the first case of the disease was reported in the Democratic Republic of Congo in 1959, approximately 33 million people globally have suffered from the epidemic [1]. According to UNAIDS, the number of people infected with HIV has risen by $27 \%$ over the past decade [2]. Although the total number
Address for correspondence: Mr. Smith Boonchutima, Chulalongkorn University, 254 Phayathai Road, Pathumwan, Bangkok, Thailand, 10330, phone: +66816469343 ,

e-mail: smith.b@chula.ac.th
Article history:

Received: 25.04.2017

Received in revised form: 05.08.2017

Accepted: 04.10.2017

Available online: 30.11.2017
International Journal of HIV-Related Problems

HIV \& AIDS

R e vi e w 
of new HIV infections has been declining every year owing to the heightened access to antiretroviral therapy, the epidemic remains a major burden in Asia and particularly in Thailand $[2,3]$. Thailand has approximately 2.5 million migrants, the majority of whom entered the nation illegally through its porous borders with Laos, Cambodia, and Burma. Conflicts, high poverty, and limited economic opportunities encourage migrants to come to Thailand in search of refuge and greener pastures to support their families and realise their future endeavours [4]. Enticements in Thailand include numerous employment opportunities, particularly in sectors such as agriculture, domestic work, construction, and fishing. A majority of Burmese migrants come into Thailand without legal documentation and their illegal immigrant status, making them predominantly underserved in regard to access to HIV/AIDS healthcare services $[5,6]$.

The prevalence of HIV/AIDS in Thailand has been gradually declining over the years due to successful HIV/ AIDS prevention programs [3]. Nonetheless, according to the UNAIDS Gap Report 2016, there were around 440,000 people living with HIV in Thailand with the adult prevalence rate reported at $1.1 \%$ [2]. Thousands of undocumented and documented migrants such as from Myanmar have significant HIV/AIDS problems in their homeland and increase the prevalence of the epidemic by illegally migrating into Thailand [6]. According to UNAIDS, the HIV prevalence in Burma has increased consistently over the years from $0.3 \%$ in $1992,1 \%$ in 2000 and $1.23 \%$ in year 2003 [2]. Researchers have confirmed that Burmese migrants are likely to engage in risky sexual behaviours, a situation which aggravates the prevalence of HIV/AIDS in Thailand [5]. Burmese migrants work and live with the constant fear of being arrested, hence are unable to access HIV/AIDS health care services or to interact with public health officers working in the department of Disease Control [7]. In addition, a majority have tight working schedules that make it impossible to visit healthcare facilities during opening hours. Many of the Burmese migrants have little or no knowledge about the treatment and prevention of HIV/AIDS, and family separations coupled with the proliferation of sex services increases the transmission of HIV/AIDS [6, 8].

Migration is recognised as one of the structural factors responsible for the spread of HIV/AIDS. According to a 2010 research entitled "Migration and HIV/AIDS in Thailand: Triangulation of biological, behavioural, and programmatic response data in selected provinces" it was revealed that the current migrant health information systems in Thailand offer a wide range of information about HIV/ AIDS, but are insufficient and warrant improvement [8]. The report also found that the diverse migrant population groups in Thailand necessitate adoption of diverse strategies to contain the prevalence of HIV/AIDS. The study manifested doubt about the effectiveness of the existing HIV/AIDS surveillance systems in Thailand in curbing the HIV/AIDS problem [8].

Health communication plays a critical role in the prevention of HIV globally. Communication can create health-seek- ing conduct and motivate people to adopt HIV prevention strategies such as condom use, HIV testing, and voluntary male circumcision. Literature has consistently documented that HIV health communication strategies can shift attitudes, enhance knowledge, and initiate changes in HIV-related tendencies $[9,10]$. It can link HIV/AIDS patients to psychosocial and medical care, improve access to treatment, and assist in reducing the stigma that inhibits individuals from adopting these measures. HIV/AIDS health communication intervention cannot eradicate challenges associated with the epidemic without the availability of high-quality healthcare and prevention services. Biomedical interventions must be used in conjunction with HIV/AIDS health communication initiatives to ensure that the epidemic is eradicated in Thailand [11]. Even though health communication interventions play a central role in the prevention of HIV, its potential is yet to be fully realised. This is largely due to the absence of a framework for transforming health communication practices into particular interventions [12].

This study has delved into details on the issues raised by the above 2010 study titled "Migration and HIV/AIDS in Thailand: Triangulation of biological, behavioural, and programmatic response data in selected provinces". The researchers observe that the public health department of any nation plays a critical role in the success of infection control programs. The Bureau of Risk Communication and Health Behaviour Development is identified as one of the institutes of the Department of Disease Control (DDC) in Thailand critical in successfully executing this function. As a primary entity of the DDC, it is tasked with pursuing the mission aligning with its parent organisation, which is to "develop and produce timely information, knowledge, and tools for effective surveillance, prevention, and control of communicable and non-communicable diseases". The Bureau has a network of public health officers working all over the country. Their mandate is to keep up with the surveillance and educate the public regarding how to prevent infectious diseases, as well as to suggest new measures for halting the spread of emerging and existing HIV infections.

It is critical to note that HIV, including other viruses, can only survive in living cells, and their transmission rates vary from virus to virus $[13,14]$. With respect to HIV, it is transmitted through bodily fluid exchange with sexual transmission considered as the primary way for the spread of this disease. Educating the public concerning the treatment and prevention of HIV/AIDS can play a significant role in halting the disease. For instance, educating migrants concerning correct condom use can lower the transmission of HIV and perception about condoms [15]. Moreover, promoting access to antiretroviral drugs such as Nevirapine can significantly reduce mother-to-child HIV transmission, provided expectant mothers are aware of the public health knowledge relevant to HIV/AIDS [16]. Major concerns arising in the dissemination of public health knowledge about HIV/ AIDS include the training and education of the general public about preventive health care strategies. Besides, non-governmental organisations play a crucial role in national public 
health programs, ensuring that information is provided to every person residing in the country. Unfortunately, migrants' training concerning the treatment and prevention of HIV/AIDS has remained a global issue due to language and knowledge and attitudes towards HIV/AIDS [17].

This study is based on the experience of public health officers working in the Bureau of Risk Communication and Health Behaviour Development, Department of Disease Control (DDC) in Thailand. These workers were selected to complete this research since they have first-hand information concerning the interaction levels between Public Health Officers working in the Department of Disease Control, Thailand and Burmese migrants in communicating knowledge on HIV/AIDS. The public health officers understand perfectly the issue being evaluated in this study with an exception of matters relevant to governance and management of the Department where a few officers shun to respond. Nonetheless, there was nearly $100 \%$ response rate, which enabled the researcher to collect data and make informed deliberations on the subject. The public health officer's perspective is critical in regard to preventive measures relevant to HIV/AIDS for Burmese migrants. Although this study identifies governance issues within the department relevant to policy matters and procedures related to the education of Burmese migrants about HIV/AIDS, the public officers also exemplified concern about migrants' attitudes towards the epidemic. A major concern highlighted in this research is that the translators involved in conveying the public health officers' message to the migrants encountered challenges communicating appropriate public health messages to the migrant communities, due to language barriers. It is critical to eliminate the false perception of immunity among the Burmese migrant workers in Thailand in order to lower the prevalence of HIV/AIDS in the nation. This study not only gathers first-hand information, but also it complements previously existing data relevant to migrant's HIV/AIDS status and suggests exploration of new avenues.

\section{Material and methods}

The data for this research was collected through examining the opinions of Thai public health officers about the challenges they face while communicating information concerning the risk of HIV/AIDS among Myanmar migrants in Thailand. The study population comprised personnel drawn from the Department of Disease control and the Ministry of Public health, Thailand, who are responsible for communicating the risk and prevention of AIDS among the target migrant workers. Prior to the start of this survey, general information about the 12 districts sampled in this study was obtained from the Office of Disease Prevention and Control, Bureau of HIV/AIDS and sexually transmitted diseases, Office of Risk communication and behaviour modification, Department of Disease control, and the Ministry of Public Health.

A carefully designed questionnaire approved by the Ethical Research Committee of Chulalongkorn University was employed to collect responses from public health officers. All the officers participating in this study were required to sign a consent paper regarding their participation. No personal information was recorded, to ensure the anonymity of the respondents. Consenting individuals were asked to provide information in the following dimensions:

- demographic characteristics such as sex, age, and years of experience in the department,

- frequency of individual officer interaction with Burmese migrants relevant to HIV/AIDS,

- prominent HIV/AIDS-related public health issues and preventive measures discussed by the public health officers with Burmese migrants,

- general perception of the public health officers relevant to communicating HIV/AIDS relevant public health education with Burmese migrants,

- enabling and efficient strategies for HIV/AIDS related educational programs,

- importance of HIV/AIDS relevant essential public health knowledge domains necessary to educate Burmese migrants.

An expert panel comprising of five members, two communication specialists, two HIV/AIDS experts, and an advisor on Myanmar transnational migrants evaluated the validity of the questionnaire administered to public health officers based on the criteria identified above. Furthermore, the survey items had an index of congruence above 0.50 thus satisfying the validity needs for multidimensional assessments or measures of multiple combinations of skills [18, 19]. Statistical Package for Social Sciences (SPSS) version 22 was leveraged to complete descriptive statistics and multiple correlation analysis. Percentages, means, standard deviations, weighted scores, and frequencies were completed to describe the demographic characteristics of the sample.

\section{Results}

As detailed in Table 1, a total of 106 consenting staff members drawn from the Bureau participated in this study. The gender distribution of this cohort was 40 males (38\%) and 66 females (62\%). Approximately one-third of the participants were in the age group of 23-30 years, whereas the rest were evenly distributed in the following three age groups: $31-40$ years, $41-40$ years, and 51-60 years. Regarding working experience, $46 \%$ had less than five years of work experience while $17 \%$ were seasoned workers having worked for over 31 years with this department.

The descriptive characteristics of the sampled respondents from Table 2 concerning how often the public health officers interacted with Burmese migrants in educating them about HIV/AIDS, it was revealed that more than three-quarters of the healthcare professional, translating to $77.4 \%$, had never engaged with such a type of communication with Burmese migrants over the past 12 -month period. Only $5.7 \%$ of individuals in this department had interactions once with Burmese migrants in communicating information concerning the risk, treatment, and prevention of HIV/AIDS with 
7.5\% having communicated 2-3 times, $1.9 \%$ 3-4 times, and $0.9 \%$ five times.

The findings in Table 3 show the relative percentages of the issues discussed with migrants and their relative frequency. The prevention, causes, and symptoms of HIV/ AIDS are the leading topics that health professionals have communicated with migrants. Treatment and rights of treatment were discussed less frequently, as evidenced by the percentage scores of $15.1 \%$ and $7.5 \%$, respectively.

Table 4 shows responses from the health care officers, revealing that almost one-third of the professionals believe that Burmese migrants are not important target groups according to the department's priorities in educating them with public health knowledge relevant to HIV/AIDS. Furthermore, an inherent issue perceived by the healthcare professionals is that migrants do not understand information about HIV/AIDS (Table 4). Concerning problems with media and communication, Table 4 shows that more than $50 \%$ of the public health professionals identified problems working with Burmese translators and suggested appropriate communication channels with the migrant community.

Regarding Burmese migrants' attitudes towards receiving information on HIV/AIDS, almost one-third of the Burmese migrant communities have inherent problems in receiving these important messages. They did not display cooperative behaviours in HIV/AIDS-relevant communication sessions organised by the health department, were not entirely aware of the dangers associated with the virus, believed they would never get the disease, and had no confidence in the quality of health care and prevention measures of the health departments in Thailand. Regarding responding to the department's matters of governance relevant to communicating HIV/AIDS with Burmese migrants, one-quarter of the participants abstained from responding to this question on matters relating to budget, management, and approval of projects related to HIV/AIDS by Thai authorities.

The results in Table 5 revealed that the preferred methodology for health care bureau professionals in providing information about HIV/AIDS to Burmese migrants in Thailand is in groups at their venue of work such factories, and restaurants. The second preferred type of media is posters, followed by flyers, and audio programs relayed to Burmese migrants' in their workplaces. The other strategies proposed in this questionnaire did not receive significant approval.

As detailed in Table 6, the causes and spread of HIV/ AIDS was ranked first as the variable to consider when designing public health educational programs for Burmese migrants working in Thailand. "Prevention" was ranked second, "Symptoms" third, "Treatment" fourth, and "Right to treatment" fifth in terms of the level of importance.

Table 7 shows multiple correlation values for the various variables and demographic characteristics of the study participants. It revealed that the crux of the problem is the attitude of the Health Behaviour Development, Department of Disease Control personnel towards Burmese migrants. This was manifested with a highly significant correlation co-
Table 1. Demographic characteristics of the study participants from the Bureau of Risk Communication and Health Behaviour Development, Department of Disease Control

\begin{tabular}{|c|c|c|}
\hline Demographics & Frequency & $\%$ \\
\hline \multicolumn{3}{|l|}{ Gender } \\
\hline Male & 40 & 37.7 \\
\hline Female & 66 & 62.3 \\
\hline Total & 106 & \\
\hline \multicolumn{3}{|l|}{ Age (years) } \\
\hline $23-30$ & 34 & 32.2 \\
\hline $31-40$ & 24 & 22.6 \\
\hline $41-50$ & 24 & 22.6 \\
\hline $51-60$ & 24 & 22.6 \\
\hline \multicolumn{3}{|c|}{ Years of work experience } \\
\hline Less than 5 & 49 & 46.1 \\
\hline $6-10$ & 6 & 5.7 \\
\hline $11-20$ & 18 & 17.0 \\
\hline $21-30$ & 15 & 14.2 \\
\hline$\geq 31$ & 18 & 17.0 \\
\hline
\end{tabular}

Table 2. Relative frequency of the Bureau of Risk Communication and Health Behaviour Development, Department of Disease Control personnel interactions with Burmese migrants about HIV/AIDS relevant communications over the past 12 months

\begin{tabular}{l|c|c}
\hline Number of times & Frequency & $\%$ \\
\hline Never & 82 & 77.4 \\
\hline Once & 6 & 5.7 \\
\hline 2-3 times & 8 & 7.5 \\
\hline 3-4 times & 2 & 1.9 \\
\hline 5 times & 1 & 0.9 \\
\hline More than five times & 7 & 6.6 \\
\hline
\end{tabular}

Table 3. HIV/AIDS relevant issues discussed by the Public Health Officers from the Bureau of Risk Communication and Health Behaviour Development, Department of Disease Control with Burmese migrants

\begin{tabular}{l|c|c}
\hline Issues discussed $(n=94)$ & Frequency & $\%$ \\
\hline Causes/spread & 20 & 18.9 \\
\hline Symptoms & 20 & 18.9 \\
\hline Treatments & 16 & 15.1 \\
\hline Preventions & 26 & 24.5 \\
\hline Rights to treatment & 8 & 7.5 \\
\hline Others & 4 & 3.8 \\
\hline
\end{tabular}

* Respondents can answer more than one option. Respondents who have never engaged in communications about AIDS within the past 12 months should skip this question. 
Table 4. Evaluations of hurdles faced by Bureau of Risk Communication and Health Behaviour Development, Department of Disease Control personnel associated with communicating about HIV/AIDS with Burmese migrants workers

\begin{tabular}{|c|c|c|c|c|c|c|c|c|}
\hline \multirow[t]{2}{*}{ Questions } & \multicolumn{5}{|c|}{$\begin{array}{l}\text { Level of working conditions and problems } \\
\text { faced during communication works regarding } \\
\text { AIDS among Burmese migrant workers }\end{array}$} & \multirow[t]{2}{*}{ Mean } & \multirow[t]{2}{*}{ SD } & \multirow[t]{2}{*}{ Interpretations } \\
\hline & $\begin{array}{l}\text { Very } \\
\text { little }\end{array}$ & A little & A lot & $\begin{array}{l}\text { Very } \\
\text { much }\end{array}$ & $\begin{array}{c}\text { No } \\
\text { opinion }\end{array}$ & & & \\
\hline \multicolumn{9}{|c|}{ Problems concerned with the healthcare professional } \\
\hline $\begin{array}{l}\text { 1. You feel that Burmese migrant workers } \\
\text { are not as important a target group as Thai } \\
\text { labour workers. }\end{array}$ & $\begin{array}{c}13 \\
(12.3 \%)\end{array}$ & $\begin{array}{c}42 \\
(39.6 \%)\end{array}$ & $\begin{array}{c}33 \\
(31.1 \%)\end{array}$ & $\begin{array}{c}15 \\
(14.2 \%)\end{array}$ & $\begin{array}{c}3 \\
(2.8 \%)\end{array}$ & 2.49 & 0.90 & A little \\
\hline $\begin{array}{l}\text { 2. You feel that Burmese migrant workers } \\
\text { are not capable of understanding } \\
\text { information regarding AIDS. }\end{array}$ & $\begin{array}{c}6 \\
(5.7 \%)\end{array}$ & $\begin{array}{c}42 \\
(39.6 \%)\end{array}$ & $\begin{array}{c}41 \\
(38.7 \%)\end{array}$ & $\begin{array}{c}14 \\
(13.2 \%)\end{array}$ & $\begin{array}{c}3 \\
(2.8 \%)\end{array}$ & 2.61 & 0.79 & Moderate \\
\hline \multicolumn{9}{|c|}{ Problems concerned with the media and communication } \\
\hline $\begin{array}{l}\text { 3. Not being able to communicate } \\
\text { in Burmese hinders your implementation } \\
\text { for the communication projects. }\end{array}$ & $\begin{array}{c}6 \\
(5.7 \%)\end{array}$ & $\begin{array}{c}18 \\
(17.0 \%)\end{array}$ & $\begin{array}{c}44 \\
(41.5 \%)\end{array}$ & $\begin{array}{c}27 \\
(25.5 \%)\end{array}$ & $\begin{array}{c}11 \\
(10.4 \%)\end{array}$ & 2.97 & 0.86 & Moderate \\
\hline $\begin{array}{l}\text { 4. You have experienced problems working } \\
\text { with Burmese translators. }\end{array}$ & $\begin{array}{c}8 \\
(7.5 \%) \\
\end{array}$ & $\begin{array}{c}19 \\
(17.9 \%) \\
\end{array}$ & $\begin{array}{c}27 \\
(25.5 \%) \\
\end{array}$ & $\begin{array}{c}12 \\
(11.3 \%) \\
\end{array}$ & $\begin{array}{c}40 \\
(37.7 \%) \\
\end{array}$ & 2.65 & 0.92 & Moderate \\
\hline $\begin{array}{l}\text { 5. You lack information for creating } \\
\text { communication plans. }\end{array}$ & $\begin{array}{c}18 \\
(17.0 \%) \\
\end{array}$ & $\begin{array}{c}25 \\
(23.6 \%)\end{array}$ & $\begin{array}{c}34 \\
(32.1 \%) \\
\end{array}$ & $\begin{array}{c}13 \\
(12.3 \%) \\
\end{array}$ & $\begin{array}{c}16 \\
(15.1 \%) \\
\end{array}$ & 2.47 & 0.97 & A little \\
\hline $\begin{array}{l}\text { 6. Information regarding AIDS is constantly } \\
\text { changing. }\end{array}$ & $\begin{array}{c}14 \\
(13.2 \%)\end{array}$ & $\begin{array}{c}59 \\
(55.7 \%)\end{array}$ & $\begin{array}{c}21 \\
(19.8 \%)\end{array}$ & $\begin{array}{c}4 \\
(3.8 \%)\end{array}$ & $\begin{array}{c}8 \\
(7.5 \%)\end{array}$ & 2.15 & 0.71 & A little \\
\hline $\begin{array}{l}\text { 7. You lack suitable media channels for } \\
\text { communicating with Burmese migrant } \\
\text { workers. }\end{array}$ & $\begin{array}{c}4 \\
(3.8 \%)\end{array}$ & $\begin{array}{c}23 \\
(21.7 \%)\end{array}$ & $\begin{array}{c}37 \\
(34.9 \%)\end{array}$ & $\begin{array}{c}27 \\
(25.5 \%)\end{array}$ & $\begin{array}{c}15 \\
(14.1 \%)\end{array}$ & 2.96 & 0.86 & Moderate \\
\hline \multicolumn{9}{|c|}{ Problems at the receiving end the Burmese workers } \\
\hline $\begin{array}{l}\text { 8. Burmese migrant workers are obstructed } \\
\text { from receiving information. }\end{array}$ & $\begin{array}{c}15 \\
(14.2 \%)\end{array}$ & $\begin{array}{c}51 \\
(48.1 \%)\end{array}$ & $\begin{array}{c}11 \\
(10.4 \%)\end{array}$ & $\begin{array}{c}4 \\
(3.8 \%)\end{array}$ & $\begin{array}{c}25 \\
(23.6 \%)\end{array}$ & 2.05 & 0.72 & A little \\
\hline $\begin{array}{l}\text { 9. Burmese migrant workers do not } \\
\text { cooperate during the communication. }\end{array}$ & $\begin{array}{c}5 \\
(4.7 \%) \\
\end{array}$ & $\begin{array}{c}34 \\
(32.1 \%) \\
\end{array}$ & $\begin{array}{c}35 \\
(33.0 \%) \\
\end{array}$ & $\begin{array}{c}2 \\
(1.9 \%)\end{array}$ & $\begin{array}{c}30 \\
(28.3 \%)\end{array}$ & 2.45 & 0.66 & A little \\
\hline $\begin{array}{l}\text { 10. Burmese migrant workers do not } \\
\text { realise or are not attentive to the danger } \\
\text { of AIDS. }\end{array}$ & $\begin{array}{c}2 \\
(1.9 \%)\end{array}$ & $\begin{array}{c}22 \\
(20.8 \%)\end{array}$ & $\begin{array}{c}43 \\
(40.6 \%)\end{array}$ & $\begin{array}{c}8 \\
(7.5 \%)\end{array}$ & $\begin{array}{c}31 \\
(29.2 \%)\end{array}$ & 2.76 & 0.67 & Moderate \\
\hline $\begin{array}{l}\text { 11. Burmese migrant workers feel so } \\
\text { disgusted about AIDS that they do not } \\
\text { want to get involved with communication } \\
\text { activities concerning AIDS. }\end{array}$ & $\begin{array}{c}4 \\
(3.8 \%)\end{array}$ & $\begin{array}{c}42 \\
(39.6 \%)\end{array}$ & $\begin{array}{c}25 \\
(23.6 \%)\end{array}$ & $\begin{array}{c}1 \\
(0.9 \%)\end{array}$ & $\begin{array}{c}34 \\
(32.1 \%)\end{array}$ & 2.32 & 0.60 & A little \\
\hline $\begin{array}{l}\text { 12. Burmese migrant workers lack } \\
\text { confidence and trust in the information } \\
\text { regarding AIDS that you provided, } \\
\text { resulting in decreased effectiveness } \\
\text { of the communication. }\end{array}$ & $\begin{array}{c}12 \\
(11.3 \%)\end{array}$ & $\begin{array}{c}44 \\
(41.5 \%)\end{array}$ & $\begin{array}{c}13 \\
(12.3 \%)\end{array}$ & $\begin{array}{c}4 \\
(3.8 \%)\end{array}$ & $\begin{array}{c}33 \\
(31.1 \%)\end{array}$ & 2.12 & 0.74 & A little \\
\hline $\begin{array}{l}\text { 13. Burmese migrant workers do not } \\
\text { believe that they are prone to the risks } \\
\text { that you told them, resulting in decreased } \\
\text { effectiveness of the communication. }\end{array}$ & $\begin{array}{c}3 \\
(2.8 \%)\end{array}$ & $\begin{array}{c}24 \\
(22.7 \%)\end{array}$ & $\begin{array}{c}35 \\
(33.0 \%)\end{array}$ & $\begin{array}{c}10 \\
(9.4 \%)\end{array}$ & $\begin{array}{c}34 \\
(32.1 \%)\end{array}$ & 2.72 & 0.75 & Moderate \\
\hline $\begin{array}{l}\text { 14. Burmese migrant workers do not have } \\
\text { confidence in the quality of health care } \\
\text { and prevention of the health departments } \\
\text { in Thailand. }\end{array}$ & $\begin{array}{c}29 \\
(27.4 \%)\end{array}$ & $\begin{array}{c}31 \\
(29.2 \%)\end{array}$ & $\begin{array}{c}15 \\
(14.2 \%)\end{array}$ & $\begin{array}{c}3 \\
(2.8 \%)\end{array}$ & $\begin{array}{c}28 \\
(26.4 \%)\end{array}$ & 1.90 & 0.85 & A little \\
\hline
\end{tabular}


Table 4. Cont.

\begin{tabular}{|c|c|c|c|c|c|c|c|c|}
\hline \multicolumn{9}{|l|}{ Problems concerned with management } \\
\hline $\begin{array}{l}\text { 15. You have not received sufficient budget } \\
\text { for implementation of communication } \\
\text { projects regarding the risk of AIDS among } \\
\text { Burmese migrant workers. }\end{array}$ & $\begin{array}{c}9 \\
(8.5 \%)\end{array}$ & $\begin{array}{c}25 \\
(23.6 \%)\end{array}$ & $\begin{array}{c}30 \\
(28.3 \%)\end{array}$ & $\begin{array}{c}17 \\
(16.0 \%)\end{array}$ & $\begin{array}{c}25 \\
(23.6 \%)\end{array}$ & 2.68 & 0.93 & Moderate \\
\hline $\begin{array}{l}\text { 16. You have not received support from } \\
\text { the management team for implementing } \\
\text { the communication projects. }\end{array}$ & $\begin{array}{c}10 \\
(9.4 \%)\end{array}$ & $\begin{array}{c}37 \\
(34.9 \%)\end{array}$ & $\begin{array}{c}25 \\
(23.6 \%)\end{array}$ & $\begin{array}{c}5 \\
(4.7 \%)\end{array}$ & $\begin{array}{c}29 \\
(27.4)\end{array}$ & 2.32 & 0.79 & A little \\
\hline $\begin{array}{l}\text { 17. You have experienced problems } \\
\text { in requesting approvals for } \\
\text { the communication projects. }\end{array}$ & $\begin{array}{c}17 \\
(16.0 \%)\end{array}$ & $\begin{array}{c}29 \\
(27.4 \%)\end{array}$ & $\begin{array}{c}21 \\
(19.8 \%)\end{array}$ & $\begin{array}{c}6 \\
(5.7 \%)\end{array}$ & $\begin{array}{c}33 \\
(31.1 \%)\end{array}$ & 2.22 & 0.90 & A little \\
\hline
\end{tabular}

Table 5. Bureau of Risk Communication and Health Behaviour Development, Department of Disease Control personnel proposed strategies for communicating HIV/AIDS-relevant public health knowledge with Burmese migrants

\begin{tabular}{|c|c|c|}
\hline Types of media $(n=455)$ & Frequency & $\%$ \\
\hline Flyers & 60 & 56.6 \\
\hline Posters & 70 & 66.0 \\
\hline Brochures & 16 & 15.1 \\
\hline Exhibitions & 20 & 18.9 \\
\hline VCDs/Short films & 47 & 44.3 \\
\hline Audio announcements at factory production lines & 61 & 57.5 \\
\hline Advertisements during local television programs & 32 & 30.2 \\
\hline Advertisements during local radio programs & 28 & 26.4 \\
\hline Mobile phone SMS & 8 & 7.5 \\
\hline Messages (posts) with pictures via Facebook and other social media channels & 21 & 19.8 \\
\hline Providing health education to groups at factories & 73 & 68.9 \\
\hline Providing health education to groups at hospitals & 14 & 13.2 \\
\hline Other (please specify) & 5 & 4.7 \\
\hline
\end{tabular}

${ }^{*}$ Respondents can choose no more than five options (every type of media uses Burmese as the primary language of communication and has been produced with the participation of Burmese migrant workers).

efficient value of 0.213 for the statement "You feel that Burmese migrant workers are not as important a target group as Thai labour workers" suggesting an overall change in behaviour and priorities of this organisation as far as Burmese migrant HIV/AIDS-relevant education in Thailand is concerned. This also corroborates with the governance-related statement "You have not received support from the management team for implementing the communication projects", where a correlation coefficient value of 0.204 was generated. Nonetheless, regarding the statement "Not being able to communicate in Burmese hinders your implementation for the communication projects", the correlation coefficient value was -0.272 .

\section{Discussion}

This study was conducted with the expectation of evaluating the ongoing efforts and the perception of public health officers from the Bureau of Risk Communication and Health
Behaviour Development, and the Department of Disease Control about Burmese migrants' public health knowledge on HIV/AIDS. The number of females who participated in this study was significantly higher than the number of male workers, with the majority of the respondent being between 23-30 years. The majority of the public health officers (46\%) had less than five years working experience with only $17 \%$ having worked for over 31 years. One of the major findings in this study is that more than three-quarters of the public health officers (77.4\%) had never engaged with Burmese migrants in communicating information about HIV/AIDS over the past 12 months. Only $5.7 \%$ of the officers had interacted once with Burmese migrants in communicating information concerning the risk, treatment, and prevention of HIV/AIDS. Although the Bureau of Risk Communication and Health Behaviour Development, Department of Disease Control had a diversified team, which would have effectively communicated HIV/AIDS information to Burmese migrants, the personnel were either disinterested in conveying 
Table 6. HIV/AIDS-relevant knowledge domains to be considered for designing public health educational programs for Burmese migrants working in Thailand

\begin{tabular}{|c|c|c|c|c|c|c|}
\hline Issue & Level of importance & $\begin{array}{c}\text { Number } \\
\text { of respondents }\end{array}$ & Scores & $\begin{array}{l}\text { Total } \\
\text { scores }\end{array}$ & $\begin{array}{l}\text { Weighted } \\
\text { value }\end{array}$ & Ranking \\
\hline \multirow[t]{5}{*}{ 1. Causes and spread } & Most important & 44 & 220 & \multirow{5}{*}{410.4} & \multirow{5}{*}{3.87} & \multirow{5}{*}{1} \\
\hline & Very important & 36 & 144 & & & \\
\hline & Moderately important & 9 & 27 & & & \\
\hline & Not so important & 9 & 18 & & & \\
\hline & Least important & 7 & 7 & & & \\
\hline \multirow[t]{5}{*}{ 2. Symptoms } & Most important & 11 & 55 & \multirow{5}{*}{316.8} & \multirow{5}{*}{2.99} & \multirow{5}{*}{3} \\
\hline & Very important & 26 & 104 & & & \\
\hline & Moderately important & 42 & 126 & & & \\
\hline & Not so important & 15 & 30 & & & \\
\hline & Least important & 9 & 9 & & & \\
\hline \multirow[t]{5}{*}{ 3. Treatment } & Most important & 3 & 15 & \multirow{5}{*}{232.2} & \multirow{5}{*}{2.19} & \multirow{5}{*}{4} \\
\hline & Very important & 11 & 44 & & & \\
\hline & Moderately important & 26 & 78 & & & \\
\hline & Not so important & 46 & 92 & & & \\
\hline & Least important & 16 & 16 & & & \\
\hline \multirow[t]{5}{*}{ 4. Prevention } & Most important & 42 & 210 & \multirow{5}{*}{398.8} & \multirow{5}{*}{3.76} & \multirow{5}{*}{2} \\
\hline & Very important & 26 & 104 & & & \\
\hline & Moderately important & 18 & 54 & & & \\
\hline & Not so important & 15 & 30 & & & \\
\hline & Least important & 4 & 4 & & & \\
\hline \multirow[t]{5}{*}{ 5. Rights to treatment } & Most important & 12 & 60 & \multirow{5}{*}{148.6} & \multirow{5}{*}{1.40} & \multirow{5}{*}{5} \\
\hline & Very important & 5 & 20 & & & \\
\hline & Moderately important & 8 & 24 & & & \\
\hline & Not so important & 16 & 32 & & & \\
\hline & Least important & 63 & 63 & & & \\
\hline
\end{tabular}

this information or utilised inappropriate communication methods.

In a study by Williams et al. (2008), selecting an appropriate medium of communication was found to be essential in effectively disseminating information about the epidemic [20]. On the other hand, it is possible that the migrants were inaccessible, especially due to their fear of being arrested or deported due to entering Thailand illegally [5]. Numerous studies have documented that prevention, causes, and symptoms of HIV/AIDS are the main issues that migrants are eager to understand [21-23]. This study corroborates with these findings since it was revealed that the majority of Burmese migrants were eager to learn about the prevention, causes, and symptoms of HIV/AIDS. Treatment and right to treatment were ranked last regarding the level of importance.

These findings emphasise the importance of health professionals selecting appropriate communication mediums and customising them to reach out to Burmese migrants to effectively educate them on the treatment, prevention, symptoms, and causes of HIV/AIDS. Proper education plays a significant role in preventing the spread of this epidemic in Thailand $[3,7]$.

The scientific community has been demanding the urgency of education focused on promoting safe sex to avoid HIV/AIDS transmission in Thailand. A study conducted in the year 1996 in Thailand recommended measures to counter coercion in sexual encounters, address the misperception that condom use is not necessary for steady relationships, develop safe sex negotiation skills, and reduce young women's inhibitions about acknowledging their sexuality [24, 25]. Along similar lines, another study identified migrant workers, particularly seafarers, as a group at risk for HIV infection [26]. Selection of appropriate channels to convey information about HIV/AIDS and changing of public health officers' perception about Burmese migrants is critical since migrants are compelled to work in exploitative conditions, which increase the burden of infectious diseases in the nation [27]. 
Table 7. Multiple correlation coefficient analyses

\begin{tabular}{|c|c|c|c|c|}
\hline & Gender & Age & $\begin{array}{l}\text { Years of work } \\
\text { experience }\end{array}$ & $\begin{array}{l}\text { Number of times } \\
\text { of communication }\end{array}$ \\
\hline Problems concerned with the sender & 0.023 & 0.049 & 0.002 & 0.134 \\
\hline $\begin{array}{l}\text { 1. You feel that Burmese migrant workers are not as important } \\
\text { a target group as Thai labour workers. }\end{array}$ & 0.033 & -0.036 & -0.106 & $0.213^{*}$ \\
\hline $\begin{array}{l}\text { 2. You feel that Burmese migrant workers are not capable } \\
\text { of understanding information regarding AIDS. }\end{array}$ & 0.006 & 0.134 & 0.133 & -0.017 \\
\hline Problems concerned with media and communication & 0.147 & -0.065 & -0.075 & -0.094 \\
\hline $\begin{array}{l}\text { 3. Not being able to communicate in Burmese hinders your } \\
\text { implementation for the communication projects. }\end{array}$ & 0.075 & -0.198 & $-0.272^{* *}$ & -0.110 \\
\hline $\begin{array}{l}\text { 4. You have experienced problems with working with Burmese } \\
\text { translators. }\end{array}$ & 0.229 & -0.086 & -0.111 & -0.036 \\
\hline $\begin{array}{l}\text { 4. You have experienced problems with working with Burmese } \\
\text { translators. }\end{array}$ & 0.229 & -0.086 & -0.111 & -0.036 \\
\hline 5. You lack information for creating communication plans. & 0.129 & -0.032 & -0.061 & $-0.211^{*}$ \\
\hline 6. Information regarding AIDS is constantly changing. & 0.080 & 0.039 & 0.070 & 0.058 \\
\hline $\begin{array}{l}\text { 7. You lack suitable media channels for communicating with Burmese } \\
\text { migrant workers. }\end{array}$ & 0.014 & 0.013 & 0.027 & -0.062 \\
\hline Problems concerned with the receiver & 0.030 & -0.001 & 0.022 & 0.055 \\
\hline 8. Burmese migrant workers are obstructed from receiving information. & 0.019 & -0.049 & -0.050 & -0.045 \\
\hline $\begin{array}{l}\text { 9. Burmese migrant workers do not cooperate during the } \\
\text { communication. }\end{array}$ & -0.065 & -0.153 & -0.123 & -0.177 \\
\hline $\begin{array}{l}\text { 10. Burmese migrant workers do not realise or are not attentive } \\
\text { to the danger of AIDS. }\end{array}$ & -0.203 & -0.077 & 0.013 & 0.083 \\
\hline $\begin{array}{l}\text { 11. Burmese migrant workers feel so disgusted about AIDS that they don't } \\
\text { want to get involved with communication activities concerning AIDS. }\end{array}$ & -0.146 & -0.134 & -0.026 & 0.147 \\
\hline $\begin{array}{l}\text { 12. Burmese migrant workers lack confidence and trust in the } \\
\text { information regarding AIDS that you provided, resulting in decreased } \\
\text { effectiveness of the communication. }\end{array}$ & 0.128 & -0.056 & -0.029 & 0.045 \\
\hline $\begin{array}{l}\text { 13. Burmese migrant workers do not believe that they are prone } \\
\text { to the risks that you told them, resulting in decreased effectiveness } \\
\text { of the communication. }\end{array}$ & 0.046 & -0.082 & -0.076 & 0.078 \\
\hline $\begin{array}{l}\text { 14. Burmese migrant workers do not have confidence in the quality } \\
\text { of health care and prevention of the health departments in Thailand. }\end{array}$ & 0.088 & -0.047 & -0.031 & 0.125 \\
\hline Problems concerned with management & -0.034 & 0.099 & 0.110 & 0.092 \\
\hline $\begin{array}{l}\text { 15. You have not received sufficient budget for implementation } \\
\text { of communication projects regarding the risk of AIDS among Burmese } \\
\text { migrant workers. }\end{array}$ & -0.064 & 0.140 & 0.123 & 0.071 \\
\hline $\begin{array}{l}\text { 16. You have not received support from the management team } \\
\text { for implementing the communication projects. }\end{array}$ & -0.101 & 0.107 & 0.154 & 0.204 \\
\hline $\begin{array}{l}\text { 17. You have experienced problems in requesting approvals } \\
\text { for the communication projects. }\end{array}$ & -0.066 & -0.028 & 0.027 & 0.057 \\
\hline
\end{tabular}

Attitudes towards Burmese migrants by public health officers was found to be a major barrier to the communication of HIV/AIDS information. Nearly a third of the health officers felt that Burmese migrants are not a critical target group in disseminating information about HIV/AIDS. The officers perceived the migrants not in a position to synthesise HIV/AIDS information, and perhaps perceived migrants as not a critical target group. Copious research has shown that Myanmar migrants have lower levels of information on HIV/ AIDS [20,21]. Mass media platforms employed to convey this information have either been inappropriate or unable to convey information in the right language.

A recent study PHAMIT-2 conducted in Thailand relevant to migrant workers (MWs) highlighted the need to facilitate 
the flow of information about places for HIV testing, availability of language assistance, and ensuring confidentiality of HIV testing [28]. The study recommended the involvement of employees' sponsors and migrant workers HIV/AIDS risk communication in conveying knowledge about the epidemic. This study highlights the importance of conveying HIV/AIDS information to Burmese migrants through groups in the workplace, posters, flyers, and announcements in the workplace. Since these mediums are the preferred platforms by migrants, public health professionals should leverage them to educate migrants on the causes and spread of HIV/AIDS, prevention, and symptoms as these were reported as the three primary focus areas. Nonetheless, the treatment and right to treatment should not be overlooked in communicating HIV/AIDS information as they are critical in eradicating the epidemic.

This study discovered that the major challenge towards communication of information about the causes, spread, symptoms, prevention, and treatment of HIV/AIDS among Burmese migrants is the public health officers' attitude towards these migrants. A significant number of the Burmese migrants observed that they have not received support or experienced problems in requesting approval for HIV/AIDS communication initiatives. This finding calls for the inclusion of all people in Thailand regardless of their status in communicating information on HIV/AIDS. The Centre for Disease Prevention and Control in conjunction with private and public organisations dealing with HIV/AIDS should formulate HIV/AIDS initiatives that convey information about the epidemic to the Thailand population. Intervention strategies, language, and mass media platforms should be selected based on the preference of the target group. There is ample statistical evidence that fostering knowledge about HIV/AIDS will eliminate the prevalence of the disease [29-32]. Based on all the available information, we propose robust migrant HIV/AIDS screening programs for Burmese and other migrants working in Thailand. The program should provide an opportunity for documented and undocumented migrants to be given relevant information on how to overcome the disease.

\section{Conclusions}

This study observed that a significant proportion of public health officers working in the Bureau of Risk Communication and the Health Behaviour Department indicated their limitations to communicate with Burmese migrants in respect to public health knowledge about HIV/AIDS. Health care officers expressed their concerns such as inefficient Burmese translators and lack of cooperation from migrants' community. Furthermore, a false perception exists among Burmese migrants that they are not prone to HIV/AIDS.

Based on this study, it is recommended that HIV/AIDS communication should be conducted not only to Burmese migrants but also in the whole country. HIV/AIDS is a worldwide problem that is more devastating than any terrorist activity around the globe. Educating Burmese migrants should be accomplished through appropriate communication mediums such as group communication in the workplace, post- ers, flyers, and announcements in the workplace in order to promote HIV/AIDS awareness, treatment, and prevention. In addition, the Thai government should use trained Burmese migrants to educate other migrants concerning HIV/ AIDS treatment and prevention. Utilising trained Burmese migrants to communicate information about HIV/AIDS to migrants can help to overcome language barriers and communication challenges faced by Thai health officers. The Thai government should address public health communication gaps through changing the policy for the provision of HIV/AIDS-relevant knowledge to these and other migrants, besides allocation of resources for this initiative. This will help in the overall control of HIV/AIDS in Thailand. In addition, it is recommended that healthcare professionals be specifically trained on how to educate Burmese migrants on HIV/AIDS. Targeted promotions can help in changing Burmese migrants HIV/AIDS-related behaviours. Behavioural change initiatives are presently considered as one of the best strategies for curbing the spread of HIV/AIDS. The Thai government should make documentation of Burmese migrants possible because their unregistered status makes them hard to reach due to fear of being arrested or deported.

\section{Acknowledgement}

The authors would like to thank the General Director of the Department of Disease Control, Thailand for granting us permission to collect the data among the participants. This study was approved by the Ethical Research Committee, Chulalongkorn University and funded by Faculty of Sports Science, Chulalongkorn University.

\section{Conflict of interest}

The authors declare no potential conflicts of interest with respect to the research, authorship, and/or publication of this article.

\section{References}

1. UNAIDS, 2010. UNAIDS report on the global AIDS epidemic 2010: Epidemic. USA: UNAIDS. Available at: http://www.unaids. org/globalreport/Global_report.htm.

2. UNAIDS. HIV and AIDS in Thailand. AVERT - Averting HIV and AIDS. Available at: http://www.avert.org/professionals/hiv-aroundworld/asia-pacific/thailand.

3. van Griensven F, Phanuphak N, Srithanaviboonchai K. Biomedical HIV prevention research and epidemic control in Thailand: two sides of the same coin. Sex Health 2014; 11: 180-199.

4. Centers for Disease Control and Prevention. HIV/AIDS Basics. USA: Department of Health and Human Services. Available at: http://www.cdc.gov/hiv/resources/qa/definitions.htm.

5. Mayer K, Beyrer C. HIV epidemiology update and transmission factors: risk and risk contexts $-16^{\text {th }}$ International AIDS Conference epidemiology plenary. Clin Infect Dis 2007; 44: 981-987.

6. Kramer MA, van Veen MG, de Coul E, et al. Migrants travelling to their country of origin: a bridge population for HIV transmission? Sex Trans Infect 2008; 84: 554-555.

7. Cohen MS, Hellmann N, Levy JA, et al. The spread, treatment, and prevention of HIV-1: evolution of a global pandemic. J Clin Invest 2008; 118: 1244-1254. 
8. Jitthai N, Yongpanichkul S, Bijaisoradat M. Migration and HIV/ AIDS in Thailand: triangulation of biological, behavioural and programmatic response data in selected provinces. IOM Thailand Office, Bangkok 2010.

9. Storey D, Ahanda KS. What is health communication and how does it affect the HIV/AIDS continuum of care? A brief primer and case study from New York City. J Acquir Immune Defic Syndr 2014; 66 (Suppl 3): S241-S249.

10. Obregon R, Waisbord S. Introduction. In: Handbook of Global Health Communication. Obregon R, Waisbord S (eds.). WileyBlackwell, Malden 2014; 1-5.

11. Bharath-Kumar U, Becker-Benton A, Lettenmaier C, et al. Communication and the antiretroviral treatment rollout: beyond the medical model. AIDS Educ Prev 2009; 21: 447-459.

12. Limaye RJ, Bingenheimer JB, Rimal RN, et al. Treatment-as-prevention in AIDS Control: why communication matters. J Ther Manag HIV Infect 2013; 1: 3-6.

13. Gonzalez G, Marshall JF, Morrell J, et al. Infection and pathogenesis of canine, equine, and human influenza viruses in canine tracheas. J Virol 2014; 88: 9208-9219.

14. UNAIDS. 2007 AIDS epidemic update. Available at: http://www. unaids.org/en/resources/documents/2007/20071130_2007_epiupdate_en.pdf.

15. Khawcharoenporn T, Chunloy K, Apisarnthanarak A. HIV knowledge, risk perception and pre-exposure prophylaxis interest among Thai university students. Int J STD AIDS 2015; 26: 1007-1016.

16. Coffie PA, Kanhon SK, Touré H, et al. Nevirapine for the prevention of mother-to-child transmission of HIV: a nation-wide coverage survey in Cote d'Ivoire. J Acquir Immune Def Syndr 2011; 57: S3-S8.

17. Widdows H, Marway H. A global public goods approach to the health of migrants. Public Health Ethics 2015; 8: 121-129.

18. Lundgren RE, McMakin AH. Risk communication: A handbook for communicating environmental, safety, and health risks. John Wiley \& Sons, 2013.

19. Rovinelli RJ, Hambleton RK. On the use of content specialists in the assessment of criterion-referenced test item validity. Dutch Journal of Educational Research 1977; 2: 49-60.

20. Williams B, Baker D, Bühler M, et al. Increase coverage of HIV and AIDS services in Myanmar. Conflict Health 2008; 2: 3.

21. Chantavanich S, Beesey A, Paul S. Mobility and HIV/AIDS in the Greater Mekong Subregion. Institute of Asian Studies, Chulalongkorn University 2000.

22. Khin A. HIV/AIDS problem of migrants from Burma in Thailand. 2009. Available at: http://www.burmawatch.org/com-khin-hivaids-burmese-migrants-thailand.pdf.

23. Chemnasiri T, Netwong T, Visarutratana S, et al. Inconsistent condom use among young men who have sex with men, male sex workers, and transgenders in Thailand. AIDS Education and Prevention 2010; 22: 100-109.

24. Carballo M, Grocutt M, Hadzihasanovic A. Women and migration: a public health issue. World Health Stat Q 1996; 49: 158-164.

25. Ford NJ, Kittisuksathit S. Sexual hazards for migrant workers. World Health Forum 1995; 17: 283-285

26. Ford K, Chamratrithirong A. Migrant seafarers and HIV risk in Thai communities. AIDS Educ Prev 2008; 20: 454-463.

27. Suwanvanichkij V. Displacement and disease: The Shan exodus and infectious disease implications for Thailand. Conflict and Health 2008; $2: 4$.

28. Musumari PM, Chamchan C. Correlates of HIV Testing Experience among Migrant Workers from Myanmar Residing in Thailand: A Secondary Data Analysis. PLoS One 2016; 11: e0154669.

29. Suwanvanichkij V. Displacement and disease: The Shan exodus and infectious disease implications for Thailand. Conflict and Health 2008; $2: 4$.
30. Chang F, Prytherch H, Nesbitt RC, et al. HIV-related travel restrictions: trends and country characteristics. Glob Health Action 2013; 6: 20472.

31. Todrys KW, Amon JJ. Within but without: human rights and access to HIV prevention and treatment for internal migrants. Globalization and Health 2009; 5: 17.

32. Centre européen de prévention et de contrôle des maladies. Migrant health: Epidemiology of HIV and AIDS in migrant communities and ethnic minorities in EU/EEA countries. ECDC, Stockholm 2009. 